\title{
Legal Issues regarding the NBE Guideline on Diaspora-Owned Shares in Banks
}

\section{Nemo dat qui non habet (No one gives what he/she doesn't have)}

DOI http://dx.doi.org/10.4314/mlr.v11i2.6

Tameru Wondim Agegnehu *

\begin{abstract}
This comment examines the legality of Guideline No. FIS/01/2016 issued by the National Bank of Ethiopia (on November $1^{\text {st }}$, 2016) regarding the relinquishing of shares in banks owned by foreign nationals of Ethiopian origin. It is argued that at the time of the auction, an Ethiopian born foreign national remains to be the owner of the share unless it is proved that ownership is acquired fraudulently or with criminal intention. One can only sell what he/she/it owns, and, the owners of the shares (to be relinquished in accordance with the NBE Guideline) are clearly the shareholders in whose name the shares were registered, and in effect, they are entitled to the premiums obtained during the transfer of shares by auction. If the initial acquisition of shares is considered improper, 'two wrongs don't make a right' and thus, the proper procedures for redeeming or repurchasing of shares under the Commercial Code should have been pursued upon the exit of the shareholders, in the absence of which the path taken by the NBE Guideline constitutes an act of sequestration, expropriation or forced purchase.
\end{abstract}

\section{Key terms:}

NBE 2016 Guideline · Shares in banks · Shares in insurers · Diaspora ·

Ethiopian born foreign nationals · Ethiopia

\section{Background}

I read a report by Menna Asrat on the Fortune Newspaper published in February 2017 about the bid put out by Awash Bank regarding shares owned by foreign nationals of Ethiopian origin whose certificates were surrendered to the Bank in

\footnotetext{
* Tameru Wondim Agegnehu: LL.B, (Haile Selassie I University, currently Addis Ababa University, 1972), LL.M (University of Manchester, 1981), former Vice President of the Supreme Court, and currently Attorney \& Consultant at Law, Email: tameruw@yahoo.com
} 
compliance with the November 2016 Guidelines of the NBE. ${ }^{1}$ It is to be recalled that I have aired my views on the way forward on this matter in an Article on Fortune Volume 17 No. 849 which was published on August 7, 2016.

The NBE Guidelines -which appeared three months later- broke the silence and eased some of the restrictions and ordered such 'shareholders' to return the certificates and collect share investment at par value with dividends with a cutoff date of $30^{\text {th }}$ June, 2016. The report indicated that the shares floated accordingly for sale by auction are so enormous with a par value constituting close to $1 \%$ of the paid up capital of the Bank.

I understand that many other commercial Banks were bidding for the right time to follow suit with Awash Bank and float such shares for grab to the public. Looking at the matter very closely some important legal issues come to mind in respect to the right of shareholders in general and those covered by Proclamation No.270/2002 in particular.

Some of the legal issues related with the NBE Guideline regarding the directive on shares owned by foreign nationals of Ethiopian origin include following:

a) Who are the owners of the shares at the time of sale?

b) What is the import of returning the shares under directive issued by the NBE in November 2016

c) Who has the right to transfer the shares to third parties?

d) Are the banks within their right to market the shares? and,

e) If they do, could such transfer be legally tenable or entail liability on the seller and/or the buyer.

\section{The owner of the shares at the time of sale}

The legal issues mentioned above must be examined in light of the relevant law to ward off 'invasion of property right' or the semblance thereof. To begin with the basic laws that relate to this matter are, among others:

- the Civil Code,

- the Commercial Code,

- Proclamation No. 591/2008 which was enacted to amend the Establishment law of the National Bank,

- Proclamation No. 592/2008 providing for Banking Business in Ethiopia, and,

- Proclamation No. 270/2002 governing the rights of foreigners of Ethiopian origin, the Investment law, as well as the statues of the Bank that conducts the auction.

\footnotetext{
${ }^{1}$ Guideline No. FIS/01/2016, "Manner of Relinquishing Shareholding of Foreign Nationals of Ethiopian Origin in a Bank or an Insurer”, November 1, 2016.
} 
In its section on Goods, the Civil Code provides that all goods are either movable or immovable. Accordingly objects with material existence which can move themselves or be moved by man including securities to bearer are termed corporeal chattels falling in the category of movable goods. Article 1204 of the Civil Code defines ownership as the widest right that may be had on corporeal chattel. The elements of such rights are expressed in terms of the three bundles usually described as usus, fructus and abusus. These rights are duly embodied in our law (under Article 1205 of the Civil Code) as rights to use, exploit or dispose the property as the owner thinks fit.

In principle, transfer of such chattels is effected by virtue of law or in pursuance of agreement entered into by the parties. Currencies and security to bearers are acquired in good faith and there is no strict modality for their transfer. As a matter of fact, bearer shares are the exception in Ethiopia, and shares issued by companies in the financial sector are all registered shares. In short, Ethiopia is yet to move to the era of dematerialization of shares, which abandon physical shares in favour of electronic format.

The Commercial Code provisions on the transfer of shares are consistent with corresponding provisions of the Civil Code. It is a self evident truth that both the investment law as well as the banking proclamation reserve the financial sector to domestic investors and bars foreigners from participating in those areas. Many thought that the application of these restrictions (that were made by Proclamation No. 270/2002) are waived to the Ethiopian 'diaspora' who hold the 'yellow' card.

The law reserves to the National Bank the power to approve but not to register the statutes of Banks and Insurance companies and also to issue license upon formation. All the Financial Institutions that are now poised to auction shares acquired by foreign nationals are duly operational, having completed approval, registration and licensing requirement by all those concerned including the National Bank.

The supervisory authority vested on the NBE over such entities, nowhere authorizes the NBE to deprive shareholders of their ownership right. Assuming for the moment that Proclamation 270/2002 is irrelevant albeit the principle of 'lex posterior derogate priori' or that it is imprecise, it is important to ask whether the November 2016 Guideline issued by the NBE constitutes ultra vires and thus subject to challenge before the competent courts.

The above laws fall short of providing for a situation where such foreigners are found to have invested in compliance with the prospectus of the Banks or with the awareness of the founders of the Bank. In light of the above the answer to the first issue is that the shareholder is not legally divested of its ownership right and remains owner of the share at the time of auction, and even after that unless it is manifestly proved that ownership is acquired fraudulently or with criminal intention of violating the law. 
Naturally it is not for the owners to prove absence of criminal intention, rather it is for the challenging party, be it the prosecutor or the NBE to establish it. If such criminal intention is proved, it may be argued that the ownership was invalid $a b$ initio, and unenforceable dating back to the time of its acquisition. Even then correcting such an illegality is the job of the courts and not that of administrative body.

\section{Anomalies in selling shares that the seller does not own; and options that could have been pursued}

Assuming that foreign nationals of Ethiopian origin are subject to additional restrictions beyond that indicated in Proclamation No. 270/2002, the NBE Guideline may serve as a wakeup call to the banks and to such shareholders to correct and adjust their relationship in accordance with the law, immediately or as soon as practicable. The Guideline is imprecise on the detail of divesting the shareholders of their ownership right. Nor does it indicate that the Bank should redeem or repurchase the shares from the owners. It leaves the ownership right in 'void' between the time of surrendering of the certificate by the owners and selling of the shares to the highest bidder.

That sounds as anomaly because the shareholders are -on the one handdivested of their ownership right, and on the other hand, the Bank that markets the shares is not the owner of the shares thereby acting without the will and consent of the owners. We therefore face a situation where the Bank is selling shares which it does not own nor is legally empowered-as agent- to effect the transaction.

In my view, this unnecessary complication is brought about as a result of complete disregard of the law and simple common sense. To begin with, the Bank can only transfer shares either as an owner or as an agent of third party. Agency emanates from a grant of power by a third party and it is not something which could be assumed or taken for granted. The bank was neither the owner nor agent of the shares that it offered for sale. As an entity devoid of rights -as an owner or agent- on the shares it has no right which is transferable. As a result, the transferee can neither have a better right for the simple reason that 'he/she who does not hath cannot give' which is the rendition of the age old Latin maxim 'nemo dat qui non habet'.

One easy way out could have been to negotiate a term for the transfer of shares with the owners, failing that to resort to the redemption procedure of the Code and obtain a resolution to redeem or repurchase the shares at a fixed price and have the shares transferred to the Bank, and proceed to auction them, if need be. I fully understand both redemption and repurchase are novel concepts even though they have been on the law book since 1960. But it does not hurt to try/apply them. 
Even if one assumes that the acquisition of shares by such persons is wrong, one could also argue that the procedure followed by the guideline to dispose the shares is equally wrong. And obviously, no two wrongs make a right. So the better option would have been to allow the owners to transfer the shares and quit, or to comply with the relevant provision of the Commercial Code and secure the exit of the shareholders by a resolution that allows the Bank to redeem/repurchase the shares. Other measures including those prescribed by the Guideline sound as disguised sequestration, expropriation or forced purchase, with implications of invasion of property right, which are without basis under the law.

As stated above, the right to transfer shares, emanates from the ownership right recognized under the law and confirmed by the statutes of the Bank that was approved by the NBE. However, the records do not indicate that such authority has been granted to the parties in question, or that the owner is legally divested of his ownership right or that he/she has transferred his/her right to third parties or that the banks have acquired ownership right over the shares.

\section{The issue of premiums and recent court cases}

An issue arises whether the Banks are within their right to auction the shares and appropriate the premium to themselves or NBE. The age old principle about ownership states that 'one cannot give what he has not'. Transfer is a give and take process. In that process, one needs to give in order to receive. And you give what you have and receive an amount of equivalent value from the other party. If you don't have a valid right on the item, the transferee will not have a better right either. Such transactions could be done by non-owner third parties if such parties are duly authorized to execute the deal. Otherwise, the right rests with the owners, and no one has a right to snatch away this right except by court of law. So, as long as the banks are not duly empowered by the owners, or acquire ownership right, they have no right either to sell or appropriate the premium to themselves or to that of third party.

If the sellers or those who auction the shares are without power or valid right to effect the transaction, then the transaction becomes defective to the point of being invalid and may be challenged as invasion of right before a court of law within ten years of the contract. The effect of such challenge is wide ranging affecting the legality of the contract, the recovery of lost profits and premiums and entailing compensation to the victim of the transaction. The question is therefore whether this is a risk with a likely chance of happening.

This comment is already on the wall with two decisions handed down recently (October 23, 2017 in File No. 249097, and 249098) by the $4^{\text {th }}$ Civil Bench of the Federal $1^{\text {st }}$ Instance Court in re Sophia Bekele -versus- United Bank and NBE, and a $2^{\text {nd }}$ case between the same plaintiff and United Bank and 
NBE. The plaintiff falls to the category of persons affected by the NBE Guideline. Shares in the United Bank and United Insurance which she acquired by inheritance were allegedly offered for auction at the behest of the defendants and she was only allowed to collect the par value as at $30^{\text {th }}$ June 2016. She was not allowed to collect the premiums or gains made on the disposal of the shares. Sophia took up the gauntlet and headed to the court to vindicate her right. The court ruled directing her to dispose her shares within two months and collect the proceeds, and in the event she defaults to do so within the given period, the court allowed defendants to dispose the shares and pay the proceeds to the plaintiff less the expenses incurred in processing the sale.

\section{Concluding remarks}

There have been various views on the November 2016 NBE Guideline and its implications. For example, the following was a reflection that I received from a colleague who read the initial draft of this comment:

“... our economy benefits a lot from the remittance of our Ethiopian-born relatives who reside abroad, and we, on the contrary, deny them the right to own shares in banks. The Golden Rule of 'don't do unto others what you don't want others do unto you' should have informed such directives [toward respecting the rights and benefits of] the diaspora in whose name we have designated a square in Addis ..."

This comment is not meant to deal with the substantive aspects and the legitimacy of the transfer per se, because it becomes beyond the scope of this comment. However, issues such as who owned the shares during the auction, and whether a bank (which is neither an owner nor an agent) can sell the shares that it does not own should have been considered. And apparently, the shareholders should have been the beneficiary of the premiums, i.e. the gains beyond the par value of the shares upon transfer by auction. 